\title{
Impact of blinatumomab on patient outcomes in relapsed/refractory acute lymphoblastic leukemia: evidence to date
}

This article was published in the following Dove Press journal: Patient Related Outcome Measures

\author{
Lindsey Hathaway' \\ Jeremy Michael Sen² \\ Michael Keng' \\ 'Department of Medicine, Division of \\ Hematology/Oncology, ${ }^{2}$ Department \\ of Pharmacy Services, University of \\ Virginia, Charlottesville, VA, USA
}

\begin{abstract}
Relapsed/refractory (R/R) acute lymphoblastic leukemia (ALL) is associated with a poor prognosis in both children and adults. Traditionally, there were limited options for salvage therapy, which consisted mostly of conventional chemotherapy. However, in the past 5 years, novel agents have changed our treatment strategies in this population. Blinatumomab, a bispecific CD19 directed CD3 T-cell engager, has shown to be effective in both minimal residual disease and R/R B-cell ALL. In R/R B-cell ALL, blinatumomab was associated with an improved median overall survival of 7.7 months vs 4.0 months with traditional chemotherapy (HR for death, 0.71; 95\% CI, $0.55-0.93 ; P=0.01$ ). It has distinctive side effects as compared to chemotherapy, specifically cytokine release syndrome and neurological toxicities. When compared to standard of care chemotherapy, patients have higher quality of life scores and less financial burden. Using the European Organisation for Research and Treatment of Cancer Quality of Life Questionnaire, blinatumomab-treated patients fared better and had a longer time to deterioration or death (global health status/quality of life subscale: HR $0.66 ; 95 \%$ CI $0.48-0.92 ; P=0.009$ ) compared to conventional chemotherapy. Using an incremental cost effective ratio threshold of US $\$ 150,000$ per quality adjusted life year, blinatumomab was determined to be more cost effective compared to chemotherapy with a probability of $73.7 \%$. This review summarizes the current and future data with blinatumomab in R/R B-cell ALL in the adult and pediatric population.
\end{abstract}

Keywords: acute lymphoblastic leukemia, B-cell acute lymphoblastic leukemia, relapsed/ refractory acute lymphoblastic leukemia, blinatumomab, Blincyto

\section{Background}

Acute lymphoblastic leukemia (ALL) affects both children and adults with B-cell subtype being the most common. Although ALL is a rare disease in children with only approximately 3,000 new cases per year in the US, it represents approximately $26 \%$ of all childhood cancers. ${ }^{1,2}$ In pediatric patients, approximately $90 \%$ achieve complete remission (CR) with initial induction chemotherapy, which typically consists of daunorubicin, vincristine, corticosteroids, and asparaginase. Although a number of variables correlate with prognosis, including cytogenetics, immunologic subtype, initial white blood cell count, and age, the 5-year overall survival (OS) of pediatric ALL patients is $85 \%$. However, for those that have relapsed/refractory $(R / R)$ disease, subsequent treatment is less effective and OS is worse. ${ }^{3,4}$ Refractory disease is defined as not achieving remission after standard induction therapy, and relapsed disease is relapsing after a CR with induction chemotherapy. Subsequent treatment traditionally has been in the form of more standard additional cytotoxic chemotherapy. For adult patients with ALL, their CR rates after induction chemotherapy are up to $80 \%$.
Correspondence: Michael Keng

Department of Medicine, Division of Hematology/Oncology, University of Virginia, PO Box 8007/6, Charlottesville, VA 22908, USA

Tel +l 4349244257

Fax +I 4342447534

Email MK2PV@virginia.edu 
Unfortunately, many adult patients, similar to the pediatric population, will have $\mathrm{R} / \mathrm{R}$ disease, and subsequently have a poor prognosis when administered traditional combination chemotherapy. ${ }^{5,6}$ Recently, three novel targeted therapies have been approved by the US Food and Drug Administration (FDA) for R/R disease: blinatumomab (initial approval December 2014), the antibody-drug conjugate inotuzumab ozogamicin (August 2017), and the chimeric antigen receptor (CAR) T-cell tisagenlecleucel.

Blinatumomab is a bispecific CD19-directed CD3 T-cell engager constructed using BiTE $^{\circledR}$ antibody technology. ${ }^{7}$ These recombinant, monoclonal antibodies are composed of an anti-CD19 fragment antigen-binding (Fab) region joined by a short linker to an anti-CD3 Fab region (Figure 1). CD19 is expressed nearly ubiquitously in B-cell lineage (with the exception of plasma cells), and therefore, blinatumomab is an option for most patients with $\mathrm{R} / \mathrm{R}$ B-cell ALL. Upon binding to both CD19 on B-cells and CD3 on T-cells, blinatumomab promotes activation and expansion of CD8 cytotoxic and CD4 helper T-cells resulting in lysis of malignant and normal B-cells. Due to the lack of a fragment crystallizable region, the elimination half-life of blinatumomab is only approximately 2 hours in children and adults. ${ }^{8}$ This requires administration as a 4-week continuous infusion followed by a 2-week treatment-free interval during each 6-week cycle. Blinatumomab is effective in both $\mathrm{R} / \mathrm{R}$ and minimal residual disease (MRD) positive B-cell ALL, and in addition, it has been associated with improved quality of life scores with less of a financial burden. MRD is defined as residual disease, with subclinical levels that are not detected on routine morphological examination. The current review will summarize the clinical evidence of blinatumomab in the treatment of $R / R$ B-cell ALL, focusing on the adult population. The patient outcomes and adverse events (AEs) of all the clinical trials in our literature review are summarized in Tables 1 and 2, respectively.

\section{Methods}

To create a systematic review of the literature, a PubMed search was performed. Key search words and phrases were "blinatumomab", "acute lymphoblastic leukemia", and "minimal residual disease". The major inclusion criteria were clinical trials in both pediatric and adult B-cell population using blinatumomab as treatment. All relevant articles were included in this review, and there were no articles excluded based on time period. To search for ongoing clinical trials, the website https://clinicaltrials.gov was utilized using "blinatumomab" as the search word.

\section{Clinical data in adult patients with R/R Philadelphia chromosome (Ph)-negative B-cell ALL}

To determine the clinical activity and dosing schedule of blinatumomab, an open label multicenter single arm Phase
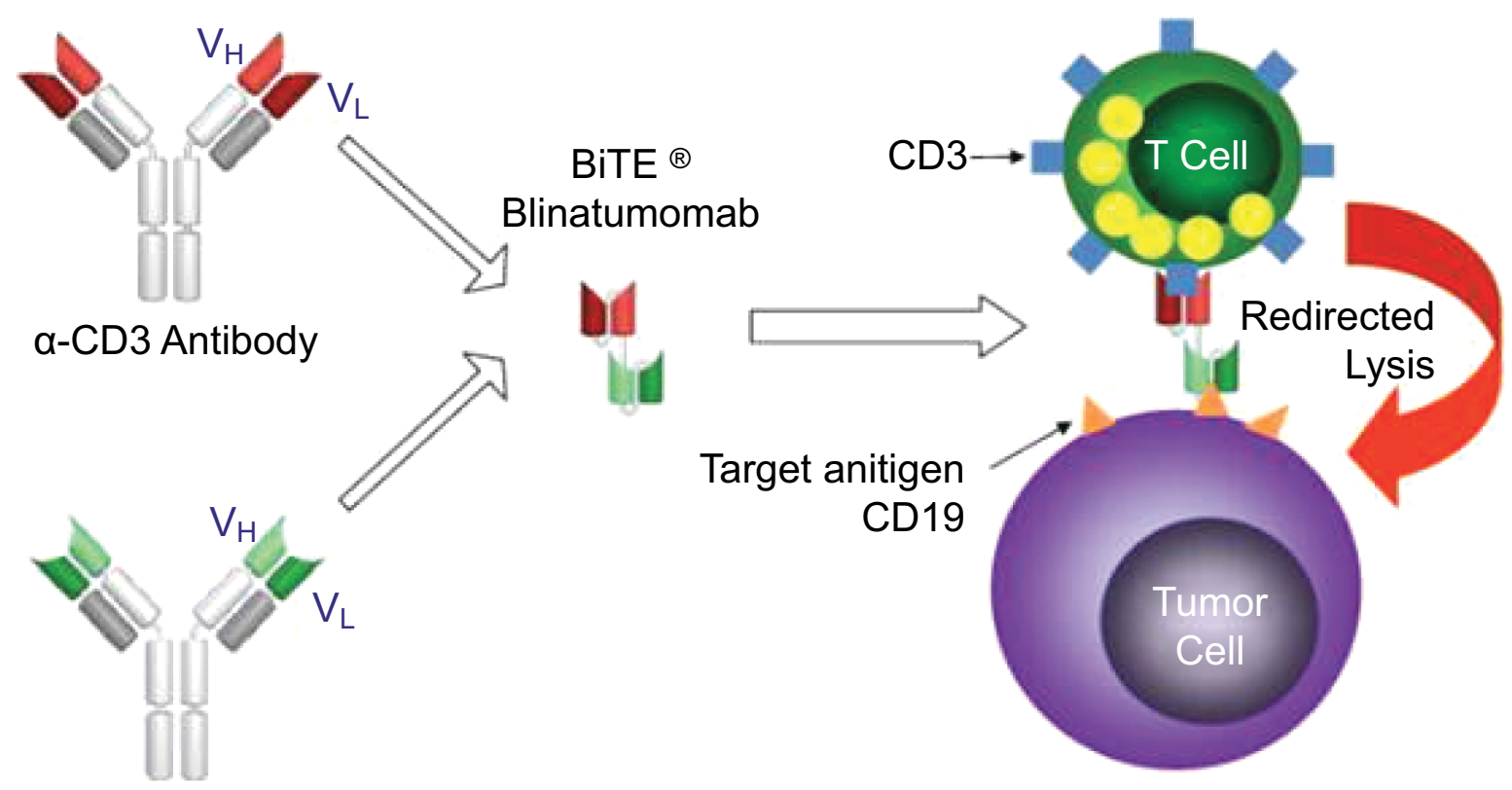

\section{a-CD19 Antibody}

Figure I Mechanism of blinatumomab.

Notes: Immunomodulatory therapy of cancer with T-cell-engaging BiTE antibody blinatumomab. Reprinted from Experimental Cell Research. 3I7(9). Nagorsen D and Baeuerle PA. Immunomodulatory therapy of cancer with T-cell-engaging BiTE antibody blinatumomab. 1255-126, 20II, with permission from Elsevier. ${ }^{25}$ 
Table I Clinical trials of blinatumomab and outcomes

\begin{tabular}{|c|c|c|c|c|c|c|}
\hline $\begin{array}{l}\text { Clinical } \\
\text { trial }\end{array}$ & $\begin{array}{l}\text { Phase of } \\
\text { trial }\end{array}$ & Population & Dosing & $\begin{array}{l}\text { Primary end } \\
\text { points }\end{array}$ & Secondary end points & $\begin{array}{l}\text { Number of } \\
\text { patients }\end{array}$ \\
\hline $\begin{array}{l}\text { Topp et al, } \\
20 \mathrm{I} \mathrm{I}^{14}\end{array}$ & Phase II & $\begin{array}{l}\text { Median age: } 47 \text { years; } \\
\text { relapsed or refractory } \\
\text { MRD B-cell ALL }\end{array}$ & $\begin{array}{l}\text { I5 } \mu \mathrm{g} / \mathrm{m}^{2} / 24 \text { hours over } 4 \text { weeks } \\
\text { with } 2 \text { weeks off of treatment } \\
\text { for a total of } 6 \text {-week cycle }\end{array}$ & $\begin{array}{l}\text { MRD response } \\
\text { rates after one cycle } \\
\text { of blinatumomab } \\
\text { RR: } 80 \%\end{array}$ & None & 20 \\
\hline $\begin{array}{l}\text { Topp et al, } \\
2014^{9}\end{array}$ & Phase II & $\begin{array}{l}\text { Median age: } 32 \text { years; } \\
\text { relapsed or refractory } \\
\text { B-cell ALL }\end{array}$ & $\begin{array}{l}\text { Cohort I: I } 5 \mu \mathrm{g} / \mathrm{m}^{2} / 24 \text { hours; } \\
\text { cohort 2: initial dose of the } \\
\text { first week of } 5 \mu \mathrm{g} / \mathrm{m}^{2} / 24 \text { hours } \\
\text { for the first week and if able } \\
\text { increased to } 15 \mu \mathrm{g} / \mathrm{m}^{2} / 24 \text { hours; } \\
\text { cohort 3: initiated at } 5 \mu \mathrm{g} / \mathrm{m}^{2} / 24 \\
\text { hours then } 15 \mu \mathrm{g} / \mathrm{m}^{2} / 24 \text { hours, } \\
\text { and then to } 30 \mu \mathrm{g} / \mathrm{m}^{2} / 24 \text { hours }\end{array}$ & CR or CRh $69 \%$ & $\begin{array}{l}\text { MRD RR } 88 \% \text {; RFS } 7.6 \\
\text { months; median OS } 9.8 \\
\text { months }\end{array}$ & 36 \\
\hline $\begin{array}{l}\text { Von } \\
\text { Stackelberg } \\
\text { et al, } 2016^{20}\end{array}$ & Phase I/II & $\begin{array}{l}\text { Median age: } 8 \text { years; } \\
\text { relapsed or refractory } \\
\text { B-cell ALL }\end{array}$ & $\begin{array}{l}\text { Phase I: maximum tolerated } \\
\text { dose of blinatumomab was I5 } \\
\mu \mathrm{g} / \mathrm{m}^{2} / 24 \text { hours, initiated at } 5 \mu \mathrm{g} / \\
\mathrm{m}^{2} / 24 \text { hours for the first week } \\
\text { and increased to } 15 \mu \mathrm{g} / \mathrm{m}^{2} / 24 \\
\text { hours }\end{array}$ & $\begin{array}{l}\text { Phase I: MTD; Phase } \\
\text { II: CR rate within } \\
\text { the first two cycles } \\
32 \%\end{array}$ & $\begin{array}{l}\text { Phase II: proportion of } \\
\text { patients HSCT post-Tx } \\
\text { among responders } 48 \% \text {; } \\
\text { RFS among responders } \\
4.4 \text { months; OS all } \\
\text { patients (70) } 7.5 \text { months }\end{array}$ & $\begin{array}{l}\text { Phase I: } 49 ; \\
\text { Phase II: } 44\end{array}$ \\
\hline $\begin{array}{l}\text { Kantarjian } \\
\text { et al, } 2017^{\prime \prime}\end{array}$ & Phase III & $\begin{array}{l}\text { Blinatumomab: } \\
\text { median age } 40.8 \\
\text { years; chemotherapy } \\
\text { median age } 41.1 \text { years; } \\
\text { relapsed or refractory } \\
\text { B-cell ALL }\end{array}$ & $\begin{array}{l}9 \mu g / 24 \text { hours for the first week, } \\
\text { and } 28 \mu g / 24 \text { hours for the } \\
\text { remainder of the } 4 \text { weeks, and } 2 \\
\text { weeks off }\end{array}$ & $\begin{array}{l}\text { Blinatumomab vs } \\
\text { chemotherapy: OS: } \\
7.7 \text { months vs } 4.0 \\
\text { months ( } 95 \% \mathrm{Cl} \text {, } \\
5.6-9.6)\end{array}$ & $\begin{array}{l}\text { Blinatumomab vs } \\
\text { chemotherapy: CR with } \\
\text { CRh within I } 2 \text { weeks: } \\
24 \% \text { vs } 16 \% \text {; } P<0.00 \text { I; } \\
\text { CR, CRh, or CRi within } \\
\text { I } 2 \text { weeks, } 44 \% \text { vs } 25 \% \text {; } \\
P<0.00 \text { I }\end{array}$ & $\begin{array}{l}\text { Blinatumomab: } \\
271 ; \\
\text { chemotherapy } \\
\text { I34 }\end{array}$ \\
\hline $\begin{array}{l}\text { Martinelli } \\
\text { et al, } 2017^{13}\end{array}$ & Phase II & $\begin{array}{l}\text { Median age: } 55 \text { years; } \\
\text { Ph-positive B-cell } \\
\text { ALL relapsed and } \\
\text { refractory }\end{array}$ & $\begin{array}{l}9 \mu g / 24 \text { hours for the first week, } \\
\text { and } 28 \mu g / 24 \text { hours for the } \\
\text { remainder of the } 4 \text { weeks, and } 2 \\
\text { weeks off }\end{array}$ & $\begin{array}{l}\text { CR or CRh during } \\
\text { first two cycles: } \\
36 \%\end{array}$ & $\begin{array}{l}\text { MRD RR during the } \\
\text { first two cycles: } 88 \% \text {; } \\
\text { RFS: } 6.7 \text { months; OS: } \\
7.1 \text { months; HSCT after } \\
\text { remission: } 44 \%\end{array}$ & 45 \\
\hline $\begin{array}{l}\text { Gökbuget } \\
\text { et al, } 2018^{19}\end{array}$ & Phase II & $\begin{array}{l}\text { Median age } 45.0 \text { years; } \\
\text { refractory MRD B-cell } \\
\text { ALL }\end{array}$ & $\begin{array}{l}\text { I5 } \mu \mathrm{g} / \mathrm{m}^{2} / 24 \text { hours over } 4 \text { weeks } \\
\text { with } 2 \text { weeks off of treatment } \\
\text { for a total of } 6 \text {-week cycle }\end{array}$ & $\begin{array}{l}\text { MRD response } \\
\text { rates after one cycle } \\
\text { of blinatumomab } \\
\text { RR: } 78 \%\end{array}$ & RFS at I 8 months: $54 \%$ & 113 \\
\hline
\end{tabular}

Abbreviations: MRD, minimal residual disease; ALL, acute lymphoblastic leukemia; RR, response rate; CR, complete remission; CRh, complete remission with partial hematological recovery; RFS, relapse-free survival; OS, overall survival; MTD, maximum tolerated dose; HSCT, hematopoietic stem cell transplantation; Cri, complete remission with incomplete blood count recovery; Ph, Philadelphia chromosome; Tx, treatment.

II study of blinatumomab in patients with R/R B-cell ALL was conducted. ${ }^{9}$ Ph-positive patients were only included if not candidates for imatinib or dasatinib. There were three blinatumomab dosing cohorts in this trial. Cohort 1 received $15 \mu \mathrm{g} / \mathrm{m}^{2} / 24$ hours; cohort 2 a started at $5 \mu \mathrm{g} / \mathrm{m}^{2} / 24$ hours for the first week and if tolerated, increased to $15 \mu \mathrm{g} / \mathrm{m}^{2} / 24$ hours for the remainder of the first cycle and for subsequent cycles; and cohort $2 \mathrm{~b}$ started at $5 \mu \mathrm{g} / \mathrm{m}^{2} / 24$ hours for the first week, $15 \mu \mathrm{g} / \mathrm{m}^{2} / 24$ hours for the second week, and then to $30 \mu \mathrm{g} /$ $\mathrm{m}^{2} / 24$ hours for the third and fourth week of the first cycle and for subsequent cycles. Patients received blinatumomab by continuous infusion for 4 weeks followed by a 2-week treatment-free interval during each 6-week cycle. After two cycles of therapy, patients who had either $\mathrm{CR}$ or complete remission with partial hematological recovery $(\mathrm{CRh})$ received three more cycles. As it is unlikely blinatumomab penetrates the central nervous system (CNS), patients all received intrathecal CNS prophylaxis in this trial. The primary end point of this trial was the number of patients with a $\mathrm{CR}$ or $\mathrm{CRh}$ during the first two treatment cycles, and other end points included MRD response rate, hematopoietic stem cell transplantation (HSCT) utilization after blinatumomab-induced remission, relapse-free survival (RFS), OS, and incidence of AEs. After 18 patients were enrolled, cohort 2a resulted in the fewest AEs, and 18 more patients were included at this dose in the expansion phase of the study. Other dosing cohorts had worse cytopenias, cytokine release syndrome (CRS), and neurological events. Table 1 summarizes this trial, along with the other landmark blinatumomab clinical trials.

In the Topp et al trial, ${ }^{9} 34 \mathrm{Ph}$-negative and two $\mathrm{Ph}$-positive patients were enrolled; 25 patients $(69 \%)$ achieved a CR or $\mathrm{CRh}$. Among patients without prior HSCT, patients who had 
Table 2 AEs of blinatumomab in patients with B-ALL in clinical trials

\begin{tabular}{|c|c|c|c|c|c|}
\hline Clinical trial & All grade $A E$ & Grade 3/4 AE & Any grade $\mathrm{AE}$ & $\begin{array}{l}\text { Treatment- } \\
\text { related deaths }\end{array}$ & $\begin{array}{l}\text { Number of } \\
\text { patients }\end{array}$ \\
\hline $\begin{array}{l}\text { Topp et al, } \\
20 \mathrm{II}^{14}\end{array}$ & $81 \%$ & $\begin{array}{l}\text { Lymphopenia } 33.3 \% \text {; blood immunoglobulin decreased } \\
23.8 \% \text {, and catheter-related infection } 9.5 \% \text {; syncope } \\
\text { and confusion } 4.8 \%\end{array}$ & $\begin{array}{l}\text { Pyrexia; chills; } \\
\text { hypokalemia }\end{array}$ & 0 & 20 \\
\hline $\begin{array}{l}\text { Topp et al, } \\
2014^{9}\end{array}$ & $100 \%$ & $\begin{array}{l}\text { Thrombocytopenia II\%; leukopenia I4\%; two } \\
\text { patients had grade } 4 \text { CRS }\end{array}$ & $\begin{array}{l}\text { Pyrexia; chills; } \\
\text { tremor, headache; }\end{array}$ & $\begin{array}{l}\text { One possibly } \\
\text { related }\end{array}$ & 36 \\
\hline $\begin{array}{l}\text { Von } \\
\text { Stackelberg } \\
\text { et al, } 2016^{20}\end{array}$ & $100 \%$ & $\begin{array}{l}\text { Anemia } 36 \% \text {, thrombocytopenia } 21 \% \text {, and febrile } \\
\text { neutropenia } 17 \% \text {, CRS in four patients } 6 \%\end{array}$ & $\begin{array}{l}\text { Pyrexia; anemia; } \\
\text { nausea, headache }\end{array}$ & 6 & 70 \\
\hline $\begin{array}{l}\text { Kantarjian } \\
\text { et al, } 2017^{\prime \prime}\end{array}$ & $\begin{array}{l}\text { Blinatumomab } \\
98.5 \% \\
\text { Chemotherapy } \\
99.1 \%\end{array}$ & $\begin{array}{l}\text { Blinatumomab: neutropenia } 37.8 \text {, infection } 34.1 \% \text {, } \\
\text { elevated liver enzyme } 12.7 \% \text {, neurological event } 9.4 \% \text {, } \\
\text { and CRS } 4.9 \% \text {; Chemotherapy: neutropenia } 57.8 \% \text {, } \\
\text { infection } 52.3 \text {, and elevation of liver enzyme } 14.7 \%\end{array}$ & $\begin{array}{l}\text { Similar compared } \\
\text { to prior studies }\end{array}$ & $\begin{array}{l}\text { Blinatumomab } 3 \% \\
\text { chemotherapy } 7 \%\end{array}$ & $\begin{array}{l}\text { Blinatumomab: } 27 \mathrm{I} \\
\text { chemotherapy } 134\end{array}$ \\
\hline $\begin{array}{l}\text { Martinelli } \\
\text { et al, } 2017^{13}\end{array}$ & $100 \%$ & $\begin{array}{l}\text { Febrile neutropenia } 27 \% \text {, thrombocytopenia } 22 \% \text {, and } \\
\text { anemia } 16 \% \text {, three patients had grade I or } 2 \text { CRS }\end{array}$ & $\begin{array}{l}\text { Pyrexia; febrile } \\
\text { neutropenia, and } \\
\text { headache }\end{array}$ & 1 & 45 \\
\hline $\begin{array}{l}\text { Gökbuget } \\
\text { et al, 2018 }\end{array}$ & $100 \%$ & $\begin{array}{l}\text { Pyrexia } 8 \% \text {; neutropenia } 14 \% \text {, and tremor } 5 \% \text {; four } \\
\text { patients had CRS }\end{array}$ & $\begin{array}{l}\text { Pyrexia; headache, } \\
\text { and neutropenia }\end{array}$ & 1 & 116 \\
\hline
\end{tabular}

Abbreviations: B-ALL, B-cell acute lymphoblastic leukemia; CRS, cytokine release syndrome; AE, adverse event.

previously been in remission but relapsed and underwent first salvage therapy with blinatumomab were more likely to achieve $\mathrm{CR} / \mathrm{CRh}(100 \% ; \mathrm{n}=11)$ than those with primary refractory disease or prior salvage therapy $(60 \% ; n=10)$. Patients who relapsed after prior HSCT also had lower CR/ $\mathrm{CRh}$ rate $(53 \% ; \mathrm{n}=15)$. MRD negativity was achieved in $88 \%$ of responders. After a follow-up period of 12.1 months, the median OS was 9.8 months.

Of the 12 responders who did not undergo HSCT after treatment, eight had relapsed disease. For the 13 patients who did undergo transplantation while in remission, six patients died of treatment-related events, two patients relapsed, and five patients had ongoing response.

Six patients died of infection during the study period; though, only one was considered possibly related to blinatumomab. The most common AEs were fever, headache, fatigue, tremor, and leukopenia. Higher grade AEs were most commonly cytopenias, including leukopenia and thrombocytopenia. Of the two patients who had grade 4 CRS, both achieved a CR and had a high tumor burden with a high number of blasts in the bone marrow or extramedullary involvement. Consequently, the remainder of high tumor burden patients received dexamethasone and cyclophosphamide prior to the initiation of blinatumomab treatment. This successfully prevented CRS in patients.

After a longer follow-up period of 32.6 months, the median OS was 13.0 months. ${ }^{10}$ The median RFS over a median follow-up duration of 28.9 months was 8.8 months. Among the patients who were determined to be long-time survivors (OS greater than 30 months), all received an MRD response. T-cell expansion was greater during cycles $1-2$ in patients among the long-term survivors. This trial showed further evidence of the clinical success of blinatumomab in $\mathrm{R} / \mathrm{R}$ B-cell ALL. In addition, it conveyed the optimal dosing schedule of the drug, and showed that long-term survivors showed an early T-cell expansion.

From January 2014 to September 2015, the TOWER trial randomized adult patients with $\mathrm{R} / \mathrm{R}$ Ph-negative B-cell ALL to either blinatumomab or standard of care chemotherapy. ${ }^{11}$ Blinatumomab was given as a fixed-dose of $9 \mu \mathrm{g} / 24$ hours (corresponding to $5 \mu \mathrm{g} / \mathrm{kg} / 24$ hours) for the first week, 28 $\mu \mathrm{g} / 24$ hours (corresponding to $15 \mu \mathrm{g} / \mathrm{kg} / 24$ hours) for the remainder of cycle 1 and for subsequent cycles. The chemotherapy group received investigator's choice of four different regimens, including FLAG (fludarabine, cytarabine, filgrastim) \pm anthracycline, HiDAC (high-dose cytarabine) \pm anthracycline \pm additional combination chemotherapy, high-dose methotrexate in combination with additional chemotherapy, and clofarabine \pm additional combination chemotherapy.

There were 405 patients randomized 2:1 to blinatumomab $(n=267)$ vs chemotherapy $(n=134)$. Median OS was 7.7 months in the blinatumomab arm $(n=267)$ and 4.0 months in the chemotherapy arm (HR for death, $0.71 ; P=0.01$ ). Eventfree survival (6-month estimates, $31 \%$ vs $12 \%, P<0.001$ ) and $\mathrm{CR}$ rates $(33.6 \%$ vs $15.7 \%, P<0.001)$ were also higher in the blinatumomab group.

In Kantarjian et al's trial, ${ }^{11}$ serious AEs occurred in $62 \%$ of patients in the blinatumomab group and in $45 \%$ in the chemotherapy group. Fatal AEs believed to be due 
to therapy were $3 \%$ in the blinatumomab group and $7 \%$ in the chemotherapy group. The most prevalent grade $\geq 3 \mathrm{AEs}$ in both groups included neutropenia, infection, and elevation in liver enzyme. Grade $\geq 3$ neutropenia was $37.8 \%$ in the blinatumomab group, and $57.8 \%$ in the chemotherapy group, and infections were $34.1 \%$ and $52.3 \%$ respectively. There were similar grade $\geq 3$ events between both arms in terms of elevation in liver enzymes and neurological events. CRS was greater in the blinatumomab group than the chemotherapy group, $4.9 \%$ vs $0 \%$. Quality of life scores were also improved in the blinatumomab group compared to the chemotherapy group.

This randomized trial showed that blinatumomab compared to chemotherapy regimens in R/R B-cell ALL improved OS. Although blinatumomab was associated with an increase in CRS, this did not prevent the patients from receiving further treatment. Furthermore, there were less grade $\geq 3$ AEs in regard to neutropenia and infection in the blinatumomab treatment group and ultimately better quality of life scores.

In addition to improvement in OS, blinatumomab was associated with better patient-reported health-related quality of life (HRQL) scores than standard of care (SOC) chemotherapy. ${ }^{12}$ In the study, HRQL was measured by the 30 -item European Organisation for Research and Treatment of Cancer Core Quality of Life Questionnaire (QLQ-C30). Patients in both the blinatumomab and SOC chemotherapy groups were asked to complete the 30 -item questionnaire on day 1 (baseline), day 8 (cycle 1 only), and day 15 and 29 of each cycle. Response was defined by at least a 10-point increase from baseline and deterioration as at least a 10-point decrease from baseline. To be included in the analysis, patients had to receive at least one dose of study drug $(n=376)$ and have answered the baseline and at least one post-baseline questionnaire $(n=342)$. In the blinatumomab group $(n=247)$, mean changes from baseline for global health status/quality of life (GHS/QoL), functional, and symptom subscales were mostly unchanged or minimally increased during cycle 1 . However, in patients answering the questionnaire who were treated with SOC chemotherapy $(\mathrm{n}=95)$, several functional (physical, role [work in household activities], and social) and symptom (fatigue, pain, nausea and vomiting, appetite loss, and diarrhea) scores exceeded the 10-point limit for deterioration during cycle 1 , and though the GHS/QoL score did not, it was markedly decreased relative to blinatumomab. In addition, blinatumomab was associated with longer time to deterioration (TTD) in HRQL or death for GHS/QoL (1.7 vs 1.0 months; HR $0.66 ; P=0.009$ ) as well as for most functional and symptom subscales $(\mathrm{HR}<1.0 ; P<0.05)$.
Only social functioning, insomnia, and financial difficulties failed to meet statistical significance for TTD or death. Of note, patient perception of blinatumomab financial burden is difficult to measure in the context of a manufacturersponsored clinical trial, and the minimal change in scores among blinatumomab-treated patients is likely not indicative of actual concerns encountered in the clinic.

\section{Clinical data in adult patients with R/R Ph-positive B-cell ALL}

A Phase II study investigated the clinical activity in adult patients with R/R Ph-positive B-cell ALL. ${ }^{13}$ Previous studies of blinatumomab in R/R B-cell ALL had mostly excluded $\mathrm{Ph}$-positive patients. Patients in this trial had to have been $\mathrm{R} / \mathrm{R}$ after at least one second generation tyrosine kinase inhibitor (TKI), or were intolerant to TKIs. This subgroup of B-cell ALL patients has few options for treatment after resistance or intolerance to TKI therapy. The 45 patients who were enrolled in this study received the previously described blinatumomab dose of $9 \mu \mathrm{g} / 24$ hours for the first week, and $28 \mu \mathrm{g} / 24$ hours for the remainder of the 4 weeks, and 2 weeks off. Within the first two cycles, 16 out of 45 patients $(36 \%)$ had a CR or CRh, and 14 out of 16 patients $(88 \%)$ had an MRD complete response. Of the 45 patients, a third harbored a mutation, including T315I mutation, which confers resistance to all commercially available TKIs except ponatinib. Four out of ten patients (40\%) with a T315I mutation had a complete response. Four out of 16 patients underwent an HSCT after a complete response. The AEs in the study were consistent with prior trials. The most common grade $\geq 3$ AEs were pyrexia, headache, febrile neutropenia, and cytopenias. Neurological events were common, including dizziness, tremors, paresthesias, and confusional states. Only three patients had grade 1 or $2 \mathrm{CRS}$. This study showed that blinatumomab is efficacious for patients with $\mathrm{R} / \mathrm{R} \mathrm{Ph}$-positive $\mathrm{B}$-cell ALL.

\section{Clinical data in chemotherapy- refractory MRD B lineage ALL}

In 2011, the first multicenter single arm Phase II study of blinatumomab in chemotherapy-refractory MRD B-cell ALL was published. ${ }^{14}$ In this trial, MRD positivity status was defined by a level of $\geq 10^{-4}$. MRD testing was performed by real-time PCR searching for T-cell receptor genes, recurrent chromosomal translocations, or fusion genes. Previous data have shown that the presence of these MRD markers correlated with the risk of relapsed disease. ${ }^{15-17}$ The blinatumomab regimen was based on non-Hodgkin's lymphoma (NHL) relapsed data, which consisted of a dose of $15 \mu \mathrm{g} / \mathrm{m}^{2} / 24$ hours 
administered continuously over 4 weeks followed by 2 weeks off of treatment for a total of 6 -week cycle. ${ }^{18}$ There were 21 patients enrolled in this study with the median age of 47 years (range 20-77 years). Of the 20 patients who were evaluated in this study, 16 patients $(80 \%)$ achieved molecular remission after one cycle of blinatumomab. With a median follow-up time of over a year, eight patients who achieved molecular remission went on to HSCT with no relapsed cases. Four out of the seven patients, who did not undergo transplantation, had relapsed disease during this period. There was one relapse in the brain and one relapse in the testis, which may be locations where blinatumomab was ineffective due to the lack of T-cells in these sites. The most common grade 3 or 4 events which occurred were infections, lymphopenia, and a decrease in blood immunoglobulins, and $81 \%$ of patients experienced grade 3 and 4 events. A majority of the events resolved, and there were no treatment-related deaths. Overall, these data showed that blinatumomab was effective in patients with MRD after chemotherapy.

A larger Phase II study investigated the tolerability and efficacy of blinatumomab in patients with MRD B-cell ALL in first or later $\mathrm{CR}$ and defined MRD positivity as a level $\geq 10^{-3} \cdot{ }^{19}$ The primary end point was MRD response status after one cycle of blinatumomab. The dosing of blinatumomab was the same as in the prior pilot study, and AEs were similar including cytopenias and neurological events. Compared to previous studies in R/R B-cell ALL, the flat dose blinatumomab in MRD setting had similar neurological events and cytopenias, but less CRS, which may correlate with less tumor burden. Furthermore, using a flat dose of blinatumomab shortens the need for hospitalization for dose increases. There were a total of 113 patients evaluated for MRD response. MRD response was similar to the prior study; $78 \%$ of patients were MRD negative after one cycle of therapy. The median OS was 36.5 months, and RFS was 18.9 months. These rates are similar to R/R B-cell ALL. Furthermore, patients who achieved a complete MRD response had an improved OS and RFS compared to patients who did not. There were nine out of $36 \mathrm{MRD}$ complete responders, who did not receive an HSCT, who continued to be in CR at a follow-up of 24 months. Therefore, this therapy seems to benefit some patients for a longer duration without undergoing an HSCT. Stemming from this study, the FDA expanded its approval to include B-cell ALL patients in MRD. Figure 2 depicts the FDA approval timeline for blinatumomab.

\section{Clinical data in pediatric patients with $R / R$ B lineage ALL}

In a Phase I/II study, blinatumomab was used in the $R / R$ B-cell ALL in pediatric patients. ${ }^{20}$ The Phase I study included 49 pediatric patients ranging from $2-17$ years of age. The maximum tolerated dose of blinatumomab was $15 \mu \mathrm{g} / \mathrm{m}^{2} / 24$ hours, and the best approach was $5 \mu \mathrm{g} / \mathrm{m}^{2} / 24$ hours for the first week, increased to $15 \mu \mathrm{g} / \mathrm{m}^{2} / 24$ hours for the rest of the duration of the treatment. Twenty-seven of the 70 patients (39\%) who received the recommended dosing schedule had a CR. Out of these responders, 52\% had an MRD response after the first cycle. Median RFS over a median follow-up

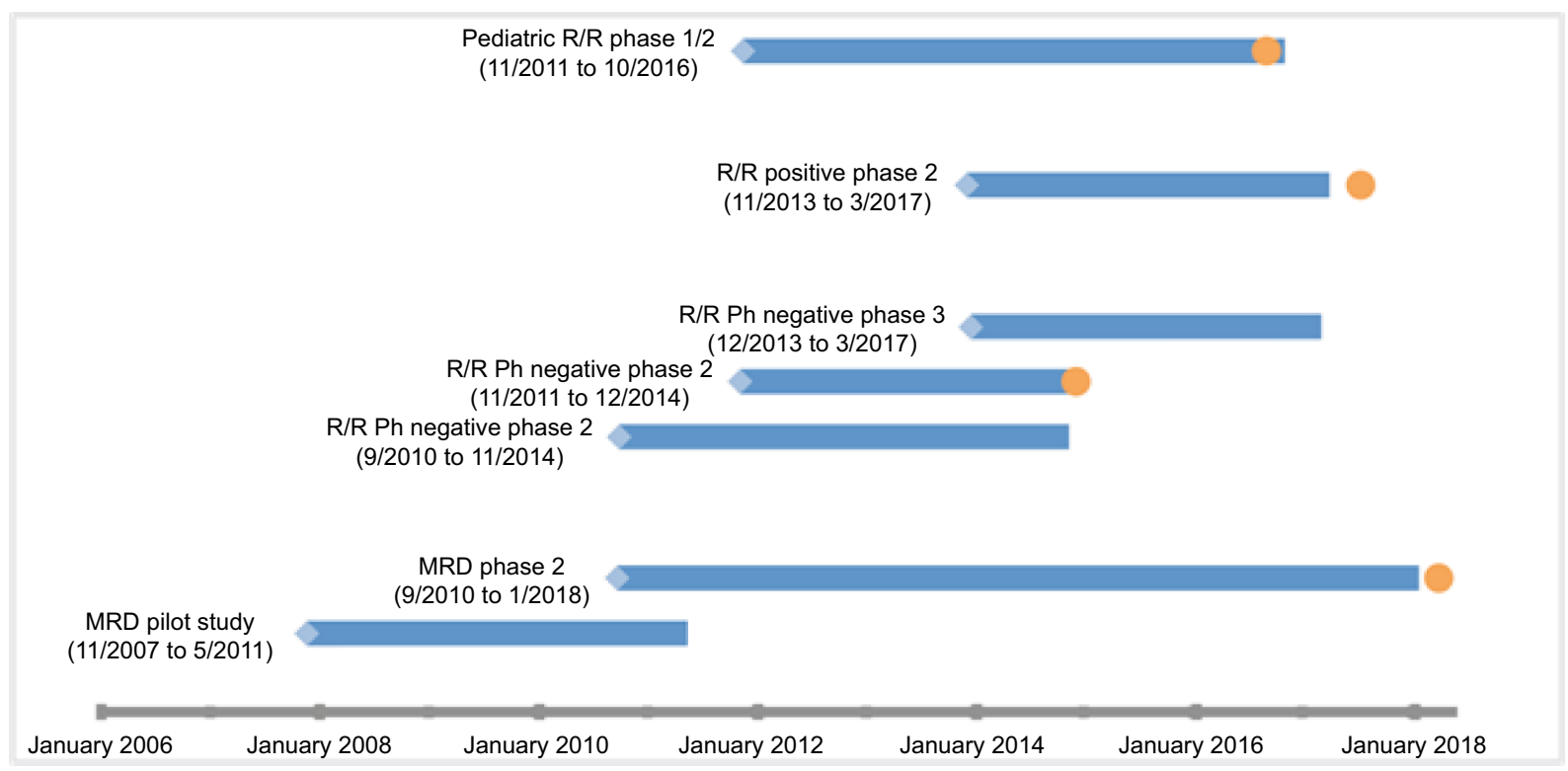

Figure 2 Development timeline of blinatumomab for the treatment of B-cell acute lymphoblastic leukemia.

Notes: Initial and end dates are time of study posting to clinicaltrials.gov and manuscript publication, respectively. Orange circles represent dates of US Food and Drug Administration approval.

Abbreviations: R/R, relapsed/refractory; Ph, Philadelphia chromosome; MRD, minimal residual disease. 
period of 23.1 months was 4.4 months. After blinatumomab treatment, 13 out of 44 patients were able to undergo an HSCT. Three patients had grade 4 CRS, and one patient had respiratory failure. The most common grade $\geq 3$ AEs were anemia, leukopenia, and hypokalemia, similar to prior studies. The most common overall AEs were also comparable to previous studies. Six percent of patients had to stop treatment due to the side effects. These data showed the potential efficacy of blinatumomab in the pediatric B-cell ALL population.

\section{Safety of blinatumomab}

While blinatumomab is generally well-tolerated relative to traditional cytotoxic chemotherapy, CRS and neurotoxicity are severe and potentially life-threatening AEs. Table 2 lists the AEs of the previously discussed blinatumomab clinical trials. CRS is a systemic inflammatory response resulting from immune system activation and is associated with an array of sudden and progressively worsening clinical manifestations including fever, malaise, capillary leak syndrome resulting in hypotension and hypoxic respiratory failure, elevated liver function tests, and in rare cases, disseminated intravascular coagulation. ${ }^{21}$ Higher tumor burden increases risk of CRS; therefore, it is most likely to occur upon initial exposure in the first cycle with a median onset of 2 days following the start of the infusion. ${ }^{8}$ In clinical trials, CRS occurred in $15 \%$ of $\mathrm{R} / \mathrm{R}$ and $7 \%$ of MRD-positive B-cell ALL. When CRS from blinatumomab therapy does not respond to drug cessation and corticosteroids, the anti-IL6 receptor monoclonal antibody, tocilizumab therapy, is used off-label for this indication. ${ }^{21}$

Neurotoxicity may occur either simultaneously with CRS or independently, and while the exact pathophysiology is uncertain, endothelial cell activation and disruption of the blood-brain barrier may allow for the crossing of inflammatory cytokines from serum to cerebrospinal fluid. ${ }^{22}$ In clinical trials, neurotoxicity occurred in $65 \%$ of patients with a median onset within 2 weeks of starting blinatumomab. Headache and tremor were most common, but severe (grade $\geq 3$ ) AEs were reported in $13 \%$ of patients and included encephalopathy, seizures, speech disorders, confusion, disorientation, difficulty with coordination or balance, and cranial nerve deficits.

Hospitalization for close monitoring of AEs is recommended for at least the first 3 days (MRD-positive indication) or 9 days ( $R / R$ indication) of the first cycle and at least 2 days of the second cycle. ${ }^{8}$ If tolerated, subsequent days may be administered at home via an ambulatory pump. To decrease the risk of CRS, intravenous corticosteroid should be administered 1 hour prior to the start of the infusion, prior to any dose increase, and prior to restarting an infusion that has been interrupted for 4 hours or more. For grade $\geq 3 \mathrm{CRS}$, grade $\geq 3$ neurotoxicity, or seizures, blinatumomab infusion should be interrupted. Though symptoms typically resolve, and patients are usually successfully rechallenged, it is recommended to consider permanent blinatumomab discontinuation for grade 4 AEs or recurrent seizures.

\section{Cost effectiveness of blinatumomab compared to standard of care}

As noted previously, in the Phase III TOWER study, blinatumomab compared to standard of care chemotherapy was associated with an improvement in OS and better quality of life scores. There was a cost effectiveness analysis of blinatumomab vs chemotherapy from the TOWER study. ${ }^{23}$ The final analysis showed that there was an increase in life years of approximately 2 years comparing blinatumomab and standard chemotherapy. Blinatumomab therapy was associated with greater treatment-related cost compared to standard of care chemotherapy (US\$395,094 vs US\$214,452, respectively). In comparing the incremental cost effectiveness between blinatumomab vs standard of care chemotherapy, which is used to determine the cost effectiveness of an intervention in health care, it was determined to be $\$ 110,108$ per quality adjusted life year (QALY) gained. Typically, oncologic treatments are determined to be cost effective if they are US\$150,000 to US\$300,000 per QALY. Using an incremental cost effective ratio threshold of US150,000 per QALY, blinatumomab was determined to be more cost effective compared to chemotherapy with a probability of $73.7 \%$. Of note, the patients without prior salvage chemotherapy had the greatest incremental cost effectiveness ratio. These results show that blinatumomab is not only a beneficial treatment option for relapsed ALL, but also can be more cost effective than traditional standard chemotherapy. ${ }^{23}$

\section{Future directions}

Another antibody that has had success in R/R B-cell ALL is the novel anti-CD22 antibody-drug conjugate, inotuzumab ozogamicin. There has been no direct comparison of these antibodies, but both have Phase III data that suggest a benefit over traditional chemotherapy in R/R B-cell ALL. ${ }^{11,24}$ The disadvantage to inotuzumab ozogamicin is that CD22 has to be expressed on the blasts of patients in order for it to be effective, and approximately $10 \%$ of patients with B-cell ALL lack this expression. The AE profiles are different: inotuzumab ozogamicin is associated with more hepatotoxicity, including the potential for veno-occlusive disease, and blinatumomab 
is associated with CRS and neurologic toxicities. There are no direct comparisons of cost effectiveness between these two therapies.

Due to the success of blinatumomab, there are several currently recruiting trials using the therapy in combination with other agents. For example, there are multiple studies in the relapsed setting using blinatumomab with immunotherapy, specifically anti-PD-1 monoclonal antibodies nivolumab ${ }^{26}$ and pembrolizumab. ${ }^{27}$ In addition, there is a clinical trial in $\mathrm{R} / \mathrm{R}$ ALL using the combination of blinatumomab and the Bruton's tyrosine kinase inhibitor ibrutinib. ${ }^{28}$ In the upfront treatment, a Phase III trial sponsored by the National Cancer Institute is investigating blinatumomab with combination chemotherapy. ${ }^{29}$ Finally, there is an ongoing Phase II/III study of blinatumomab vs investigator's choice of chemotherapy in patients with $\mathrm{R} / \mathrm{R}$ NHL.

At the University of Virginia Health System, our experience has been similar to that reported in clinical trials. AEs are typically transient and usually resolve with interrupting the infusion; with supportive care, which may include administering corticosteroids and in severe cases of CRS, tocilizumab; ${ }^{21}$ and with re-initiating the infusion in accordance with manufacturer recommendations. While AEs rarely prevent the use of blinatumomab, our institution mostly serves rural areas in Virginia and West Virginia and many patients must commute long distances, making administration of the 4-week continuous infusion complex. It requires close coordination with home health agencies to ensure safe delivery of the infusion, which includes regular exchanging of blinatumomab reservoirs to minimize disruptions to the continuous infusion, to monitor for AEs, and to safely care for a constantly accessed central line. Unfortunately for some patients, these challenges may preclude blinatumomab use. Since the commercial availability of inotuzumab ozogamicin, it has been more commonly selected for patients in first relapse of B-cell ALL at our institution, in part due to the more convenient weekly infusion schedule. However, results of ongoing and future studies are needed to determine the most beneficial sequencing or combination strategies with traditional multi-agent chemotherapy, blinatumomab, inotuzumab ozogamicin, CAR T-cell therapy, and allogeneic HSCT.

\section{Conclusion}

Blinatumomab is FDA-approved for both MRD and for $\mathrm{R} / \mathrm{R}$ B-cell ALL. As noted in this review, it is an effective treatment when compared to chemotherapy and it is usually welltolerated, but has side effects such as CRS and neurological toxicities that need to be monitored. Blinatumomab is associated with better quality of life scores as well as economic benefit when compared to traditional chemotherapy. Blinatumomab tends to be the most effective in patients with either low tumor burden B-cell ALL or MRD positivity. It is also used as a bridge to HSCT. Blinatumomab has been shown to be successful as a single agent, but future studies will be needed to determine if combination therapy will have a greater response, and thus, translate into further improvements in OS and quality of life for patients with MRD or R/R B-cell ALL.

\section{Disclosure}

The authors report no conflicts of interest in this work.

\section{References}

1. Ries LA, Smith MA, Gurney JG, et al, editors. Cancer Incidence and Survival Among Children and Adolescents: United States SEER Program 1975-1995. Bethesda: National Cancer Institute; 1999:179.

2. Ward E, Desantis C, Robbins A, Kohler B, Jemal A. Childhood and adolescent cancer statistics, 2014. CA Cancer J Clin. 2014;64(2):83-103.

3. Malempati S, Gaynon PS, Sather H, La MK, Stork LC; Children's Oncology Group. Outcome after relapse among children with standardrisk acute lymphoblastic leukemia: Children's Oncology Group study CCG-1952. J Clin Oncol. 2007;25(36):5800-5807.

4. Nguyen K, Devidas M, Children's Oncology Group, et al. Factors influencing survival after relapse from acute lymphoblastic leukemia: a Children's Oncology Group study. Leukemia. 2008;22(12): 2142-2150.

5. Rowe JM, et al; ECOG; MRC/NCRI Adult Leukemia Working Party. Induction therapy for adults with acute lymphoblastic leukemia: results of more than 1500 patients from the international ALL trial: MRC UKALL XII/ECOG E2993. Blood. 2005;106(12):3760-3767.

6. Stock W, Johnson JL, Stone RM, et al. Dose intensification of daunorubicin and cytarabine during treatment of adult acute lymphoblastic leukemia: results of Cancer and Leukemia Group B Study 19802. Cancer. 2013;119(1):90-98.

7. Baeuerle PA, Reinhardt C. Bispecific T-cell engaging antibodies for cancer therapy. Cancer Res. 2009;69(12):4941-4944.

8. Blincyto (blinatumomab) [package insert]. Thousand Oaks, CA: Amgen Inc; 2014.

9. Topp MS, Gökbuget N, Zugmaier G, et al. Phase II trial of the antiCD19 bispecific T cell-engager blinatumomab shows hematologic and molecular remissions in patients with relapsed or refractory B-precursor acute lymphoblastic leukemia. J Clin Oncol. 2014;32(36):4134-4140.

10. Zugmaier G, Gökbuget N, Klinger M, et al. Long-term survival and T-cell kinetics in relapsed/refractory ALL patients who achieved MRD response after blinatumomab treatment. Blood. 2015;126(24): 2578-2584.

11. Kantarjian H, Stein A, Gökbuget N, et al. Blinatumomab versus Chemotherapy for Advanced Acute Lymphoblastic Leukemia. $N$ Engl $J$ Med. 2017;376(9):836-847.

12. Topp M, Zimmerman Z, Cannell P, et al. Health-related quality of life in adults treated with blinatumomab using the acute lymphoblastic leukemia symptom scale. Blood. 2018;131(26):2906-2914.

13. Martinelli G, Boissel N, Chevallier P, et al. Complete Hematologic and Molecular Response in Adult Patients With Relapsed/Refractory Philadelphia Chromosome-Positive B-Precursor Acute Lymphoblastic Leukemia Following Treatment With Blinatumomab: Results From a Phase II, Single-Arm, Multicenter Study. J Clin Oncol. 2017;35(16): 1795-1802. 
14. Topp MS, Kufer P, Gökbuget N, Go N, et al. Targeted therapy with the T-cell-engaging antibody blinatumomab of chemotherapy-refractory minimal residual disease in B-lineage acute lymphoblastic leukemia patients results in high response rate and prolonged leukemia-free survival. J Clin Oncol. 2011;29(18):2493-2498.

15. Brüggemann M, Raff T, German Multicenter Study Group for Adult Acute Lymphoblastic Leukemia, et al. Clinical significance of minimal residual disease quantification in adult patients with standard-risk acute lymphoblastic leukemia. Blood. 2006;107(3):1116-1123.

16.Burmeister T, Marschalek R, Schneider B, et al. Monitoring minimal residual disease by quantification of genomic chromosomal breakpoint sequences in acute leukemias with MLL aberrations. Leukemia. 2006;20(3):451-457.

17. Campana D. Minimal residual disease in acute lymphoblastic leukemia. Hematology Am Soc Hematol Educ Program. 2010;2010(1):7-12.

18. Bargou R, Leo E, Zugmaier G, et al. Tumor regression in cancer patients by very low doses of a T cell-engaging antibody. Science. 2008;321(5891):974-977.

19. Gökbuget N, Dombret H, Bonifacio M, et al. Blinatumomab for minimal residual disease in adults with B-precursor acute lymphoblastic leukemia. Blood. 2018;131(14):1522-1531.

20. von Stackelberg A, Locatelli F, Zugmaier G, et al. Phase I/Phase II study of blinatumomab in pediatric patients with relapsed/refractory acute lymphoblastic leukemia. J Clin Oncol. 2016;34(36):4381-4389.

21. Frey NV, Porter DL. Cytokine release syndrome with novel therapeutics for acute lymphoblastic leukemia. Hematology Am Soc Hematol Educ Program. 2016;2016(1):567-572.

22. Wang Z, Han W. Biomarkers of cytokine release syndrome and neurotoxicity related to CAR-T cell therapy. Biomark Res. 2018;6(1):4
23. Delea TE, Amdahl J, Boyko D, et al. Cost-effectiveness of blinatumomab versus salvage chemotherapy in relapsed or refractory Philadelphiachromosome-negative B-precursor acute lymphoblastic leukemia from a US payer perspective. J Med Econ . 2017;20(9):911-922.

24. Kantarjian HM, Deangelo DJ, Stelljes M, et al. Inotuzumab Ozogamicin versus Standard Therapy for Acute Lymphoblastic Leukemia. N Engl J Med. 2016;375(8):740-753.

25. Nagorsen D, Baeuerle PA. Immunomodulatory therapy of cancer with T-cell-engaging BiTE antibody blinatumomab. Exp Cell Res 2011;317(9):1255-1260.

26. National Cancer Institute. Blinatumomab and nivolumab with or without ipilimumab in treating patients with poor-risk relapsed or refractory CD19+ precursor B-lymphoblastic leukemia. Available from: https:// clinicaltrials.gov/ct2/show/NCT02879695. Accessed September 14, 2018.

27. Wieduwilt M. Blinatumomab and pembrolizumab for adults with relapsed/refractory B-cell acute lymphoblastic leukemia with high marrow lymphoblasts. Available from: https://clinicaltrials.gov/ct2/ show/NCT03160079. Accessed September 14, 2018.

28. University of California, Davis. Ibrutinib and blinatumomab in treating patients with relapsed or refractory B acute lymphoblastic leukemia Available from: https://clinicaltrials.gov/ct2/show/NCT02997761. Accessed September 14, 2018.

29. National Cancer Institute. Combination chemotherapy with or without blinatumomab in treating patients with newly diagnosed BCR-ABLnegative B lineage acute lymphoblastic leukemia. Available from: https:/clinicaltrials.gov/ct2/show/NCT02003222. Accessed September $14,2018$.

\section{Patient Related Outcome Measures}

\section{Publish your work in this journal}

Patient Related Outcome Measures is an international, peer-reviewed open access journal focusing on treatment outcomes specifically relevant to patients. All aspects of patient care are addressed within the journal and practitioners from all disciplines are invited to submit their work as well as healthcare researchers and patient support groups.

\section{Dovepress}

The journal is included in PubMed. The manuscript management system is completely online and includes a very quick and fair peer-review system. Visit http://www.dovepress.com/testimonials.php to read real quotes from published authors. 